\title{
チームアプローチで実現するゲノム医療と薬剤師の役割
}

青森 達, ${ }^{*}, a$ 望月眞弓 $a, b$

\section{Genomic Medicine from a Team Approach and the Role of Pharmacists}

\author{
Tohru Aomori ${ }^{*, a}$ and Mayumi Mochizuki ${ }^{a, b}$ \\ ${ }^{a}$ Keio University Faculty of Pharmacy; 1-5-30 Shibakoen, Minato-ku, Tokyo 105-8512, Japan: and ${ }^{b}$ Department \\ of Pharmacy, Keio University Hospital; 35 Shinano-machi, Shinjuku-ku, Tokyo 160-8582, Japan.
}

2019 年 6 月，がん遺伝子パネル検査が保険収載 され，がんゲノム医療はいよいよ医療に実装される 段階を迎えた。

がんゲノム医療は，患者に対するゲノム検査の説 明に始まり，次世代シークエンサーを用いたゲノム 解析，解析結果に基づく治療方針の決定，疾病の予 後予測までを含めた患者への説明など多くのステッ プがあり，高度な知識・技術を集結させて初めて成 り立つ。このような高度ながん治療を患者に提供す るための拠点として，2018 年 2 月に全国で 11 施設 のがんゲノム医療中核拠点病院が指定され，がんゲ ノム医療の実践のみならず，連携病院に対する診療 支援，治験や先進医療の主導，さらには人材育成な ぞが行われるようになっている.

がんゲノム医療を実際に行うためには，主科とな る医師のほかに，病理医，看護師，検査技師，生物 統計家，遺伝カウンセラーなど，多くの分野の専門 家が連携したチームアプローチが不可欠であり，そ こにはもちろん薬物療法の専門家たる薬凨師も含ま れる. チームのメンバー一人ひとりが，がんゲノム 医療そのものと，その中での各職種の専門性を相互 に理解することが求められる。 また 2018 年 7 月に は遺伝性乳がんに対するオラパリブの保険適応が承 認され，薬剂師が服薬指導の際に患者の遺伝情報に 触れることは十分に想定されようになった。服薬指 導に家族が同席したり，本人不在で家族に薬を渡し たりするようなケースも起こり得る。このような場

a慶應義塾大学薬学部（干105-8512 東京都港区芝公園 1-5-30), $b$ 慶應義塾大学病院薬剂部（干160-8582 東京 都新宿区信濃町 35)

*e-mail: aomori-th@pha.keio.ac.jp

日本薬学会第 139 年会シンポジウム S49 序文
面に適切に対応するためには，遺伝情報の取り扱い や，患者・家族への対応方法を十分に知って準備し ておく必要がある，がんゲノム医療が今後，急速に 広がつて行く中で，その方法論や生殖細胞系列変異 の意味までを正確に理解し，チームでの活動や患者 への服薬指導ができる薬剤師の養成は急務である.

本誌上シンポジウムでは，このようなゲノム医療 の全体像，それに対するチームアプローチの中で薬 剂師に期待される役割，またその役割を果たすため に必要な資質について各分野の専門家 6 名にご執筆 頂いた。 まずはじめに, 慶應義塾大学医学部腫瘍セ ンターゲノム医療ユニット長の西原広史教授に「ゲ ノム医療に求められるシステム構築と人材につい て」と題して, 現在のゲノム医療を概説して頂い た. 次に, 岡山大学大学院医歯薬学総合研究科の冨 田秀太准教授に, 生物統計家としての役割, 遺伝子 変異解析の手法とその基礎的な知識を解説して頂い た. 3 題目は滋賀医科大学医学部附属病院薬剂部長 の寺田智祐教授に，ゲノム医療の中で薬剤師が担う ことのできる役割と必要な資質について，具体的に 例を挙げながら解説して頂いた。 次に慶應義塾大学 医学部腫瘍センターゲノム医療ユニットの四十物絵 里子特任助教からは, 病理医として患者に治療の説 明をする経験のなかから，薬剤師に対する期待を 語って頂いた。 また浜松医療センター薬剤科の宮本 康敬副科長からは，がんゲノム医療連携病院として の体制の整備と, その中での薬剂師の役割を紹介し て頂いた。最後に慶應義塾大学病院薬剂部の櫻井洋 臣主任には，「日本医療研究開発機構（Japan Agency for Medical Research and Developmemt; AMED) ゲノム創薬基盤推進研究事業 A-3」において実施し ている，ゲノム医療薬剤師養成の取り組みと，その 
成果について紹介して頂いた.

本誌上シンポジウムが，これからがんゲノム医療
に本格的に参画する薬剤師の方々にとつて，1つの 指標となれば幸いである. 